\title{
Variation in North Atlantic right whale Eubalaena glacialis occurrence in the Bay of Fundy, Canada, over three decades
}

\author{
Kimberley T. A. Davies ${ }^{1,2, *}$, Moira W. Brown ${ }^{3,4}$, Philip K. Hamilton ${ }^{4}$, \\ Amy R. Knowlton ${ }^{4}$, Christopher T. Taggart ${ }^{2}$, Angelia S. M. Vanderlaan ${ }^{5}$ \\ ${ }^{1}$ Department of Biological Sciences, University of New Brunswick, 100 Tucker Park Rd, Saint John, New Brunswick E2L 4L5, Canada \\ ${ }^{2}$ Department of Oceanography, Dalhousie University, 1355 Oxford Street, Halifax, Nova Scotia B3H 4R2, Canada \\ ${ }^{3}$ Canadian Whale Institute, Wilson's Beach, New Brunswick E5E 1S9, Canada \\ ${ }^{4}$ Anderson Cabot Center for Ocean Life at the New England Aquarium, Boston, Massachusetts 02110, USA \\ ${ }^{5}$ Ocean and Ecosystem Sciences Division, Bedford Institution of Oceanography, Dartmouth, Nova Scotia B2Y 4A2, Canada
}

\begin{abstract}
North Atlantic right whales Eubalaena glacialis (hereafter right whales) have recently shifted their distribution away from some protected feeding habitats, which suggests largescale changes in food supply have occurred. Quantifying the nature and extent of the apparent shift is key to exploring this hypothesis and planning or revising conservation strategies. This paper characterizes decadal right whale occurrence in the Bay of Fundy summer feeding habitat using data derived from $7522 \mathrm{~h}$ of survey effort collected over $30 \mathrm{yr}$ (1987 to 2016) that yielded 11483 right whale sightings. Eight occurrence descriptors were derived to quantify temporal variation in right whale presence, encounter rates and time of arrival in the Bay. Time of arrival was modeled using linear and power function models fit to annual discovery curves. Principal component analysis showed 2 modes that explained 58 and $14 \%$ of the variation in occurrence, respectively. The first mode captured a significant decline in summertime right whale occurrence beginning in 2010. The second mode captured a decadal-scale cycle in seasonal timing of occurrence, which highlighted a sharp change from early to late occupancy at the turn of the millennium. Annual occurrence during the 2010-2016 period was anomalously low in both the Grand Manan Basin critical habitat and the Bay of Fundy Traffic Separation Scheme (shipping lanes), whereas encounters in the region NW of the critical habitat containing Owen Basin and The Wolves islands may be increasing due to a distributional shift within the Bay. We discuss the consequences of these changes for both population dynamics and future conservation of the species.
\end{abstract}

KEY WORDS: North Atlantic right whale - Critical habitat - Calanus finmarchicus - Bay of Fundy · Habitat use $\cdot$ Occurrence $\cdot$ Immigration $\cdot$ Foraging ecology

\section{INTRODUCTION}

North Atlantic right whales Eubalaena glacialis are one of the most endangered whale species in the world numbering at ca. 450 (range 444-471) individuals (Pace et al. 2017). The Grand Manan Basin (GMB) in the lower Bay of Fundy is a well-known right whale feeding habitat that is typically occupied

*Corresponding author: kim.davies@unb.ca by a large portion of the population during summer (Murison \& Gaskin 1989, Woodley \& Gaskin 1996, Baumgartner et al. 2003). Right whales show a strong distributional preference for the GMB relative to other areas in the Bay of Fundy (Baumgartner \& Mate 2005, Vanderlaan et al. 2008), although many animals have also been sighted in shallower regions in some years (Kraus et al. 1982). This preference for

(C) The authors 2019. Open Access under Creative Commons by Attribution Licence. Use, distribution and reproduction are unrestricted. Authors and original publication must be credited. Publisher: Inter-Research · www.int-res.com 
the GMB is due to the presence of highly concentrated patches of right whale food, the copepod Calanus finmarchicus, that are retained within the bathymetrically constrained deep basin by gyre circulation (Murison \& Gaskin 1989, Woodley \& Gaskin 1996, Baumgartner et al. 2003, Aretxabaleta et al. 2008, 2009, Michaud \& Taggart 2011). The GMB supports several critical functions for the population including foraging (Murison \& Gaskin 1989, Baumgartner \& Mate 2003), suckling calves (Malik et al. 1999) and socializing (Parks et al. 2007, 2011), and it was identified as a critical habitat $(\mathrm{CH})$ for the species in 2009 (Brown et al. 2009, Fisheries and Oceans Canada 2014). The generally consistent distribution of right whales in this area and their endangered status have together facilitated intensive research on this habitat, including annual monitoring surveys that have taken place since the early 1980s (Brown et al. 2007, Hamilton et al. 2007).

From 2010 to the present, visual and acoustic survey data suggests that right whale occurrence has declined on average in most of the known feeding grounds in and around the Gulf of Maine, while at least one known inshore feeding habitat (Cape Cod Bay) and the mid-Atlantic have seen increases in occurrence (Davis et al. 2017, Mayo et al. 2018). Right whale reproductive rates have also declined during this period (Kraus et al. 2016, NARWC 2017, Pace et al. 2017). Visual survey effort has declined (NARWC 2017, Pace et al. 2017) or has been redistributed to search new areas (e.g. the Gulf of St. Lawrence, Daoust et al. 2017), and there are few peerreviewed studies that account for this change in visual survey effort in quantifying the nature and extent of the distributional shift (but see Mayo et al. 2018). The change in effort comes during a critical period for the species when the population is declining at a rate of ca. $1 \% \mathrm{yr}^{-1}(2010-2015$ average, Pace et al. 2017), and at least 15 carcasses were discovered during 2015 through 2017 in the southern Gulf of St. Lawrence (Daoust et al. 2017). Knowledge of the location and timing of feeding-habitat use is the foundation for right whale conservation strategies aimed at reducing mortality and serious injury from vessel strikes and fishing gear entanglements throughout their range to help reverse the decline (e.g. Vanderlaan et al. 2008, Daoust et al. 2017). Characterizing the changes that have occurred in the distribution of the species in protected areas is thus a high conservation priority.

The nature of the apparent distributional shift in both time and space and its underlying causes have yet to be determined quantitatively, however ocean- ographic impacts on food supply have been inferred as a cause of changes in both right whale distribution and calving rates in the past (Greene et al. 2013, Davies et al. 2015a, Meyer-Gutbrod et al. 2015). Increasing water temperatures in the Gulf of Maine are of concern because the region lies at the southernmost and warmest part of the $C$. finmarchicus range (Grieve et al. 2017). Changes in the regional ocean climate are projected to impact Calanus spp. in their role as right whale food. This could lead to physiological changes such as increased developmental rates (Campbell et al. 2001, Weydmann et al. 2015), shortened diapause duration (Saumweber \& Durbin 2006, Wilson et al. 2016), biogeographic changes such as extirpation from warm waters (Chivers et al. 2017), or changes to circulation patterns (Delworth et al. 2016) affecting population connectivity pathways, especially between the shelf-break and right whale habitats on the shelf (Greene et al. 2013, Davies et al. 2015a,b). There are some indications that a change in food supply has occurred, though the underlying mechanisms are not yet clear. Regular zooplankton monitoring surveys in the Maritimes, Canada, conducted since 1999 indicate that the annual abundance of $C$. finmarchicus has been 2 or more standard deviations below normal at $43 \%$ of monitoring stations or lines occupied from 2011 through $2016(n=30)$, which is a substantial change from the previous decade ( $1 \%, \mathrm{n}=72$, Johnson et al. 2017). McKinstry et al. (2013) also suggest that the energy content of diapausing C. finmarchicus in the Bay of Fundy may be decreasing. This could affect both the population dynamics of $C$. finmarchicus, which require accumulated lipid reserves to survive over winter, and the energy available to right whales when foraging on the copepods.

Making inferences about the effect of environmental change on right whale distribution requires first quantifying the nature of the right whale distributional variation in terms of timing and abundance (corrected for search effort), and then a systematic evaluation of potential causes. To that end, this paper contributes to the growing body of knowledge on variation in right whale habitat use by quantifying the spatiotemporal variation in right whale occurrence in the GMB through analysis of the longest time series of right whale monitoring data available derived from annual surveys conducted during 1987 through 2016. The goal of the analyses is to characterize the decadal, annual, seasonal and spatial variability in occurrence in this summertime feeding habitat using effort-corrected occurrence indices. 


\section{MATERIALS AND METHODS}

\subsection{Whale survey data}

Research was conducted in the GMB in the Bay of Fundy (Fig. 1) from 1987 through 2016, primarily using regular single-vessel right whale monitoring surveys conducted by the New England Aquarium (NEAq), for which survey methodologies are well documented (Brown et al. 2007). The surveys are not standard line transect surveys but do follow strict protocols for collecting data and recording survey effort. Surveys occurred during daylight hours on good weather days from 1 August through 30 September each year, resulting in an annual average $( \pm \mathrm{SD})$ of $26 \pm 12 \mathrm{~d}$ of search effort. These 2 months encompass the period when the climatological seasonal maximum in right whale population size occurs in the GMB (Brillant et al. 2015). In some years, sur- veys were also conducted in June, July and/or October. When right whales were sighted during each survey, the GPS location of the sighting and group size were recorded, and the survey vessel broke trackline to take photographs of each whale for individual photoidentification purposes using the identification database maintained at the NEAq (Hamilton et al. 2007, NARWC 2015).

Effort is critical for correcting bias when estimating whale encounter rate and location if a systematic or randomly determined search pattern is not used. During surveys, vessel location and Beaufort sea state were consistently recorded every $10 \mathrm{~min}$ prior to the year 2000 and every $1 \mathrm{~min}$ from 2000 onward. Visibility was only recorded in a useful manner beyond 2003 and therefore was not included as a measure of effort in this study. Here we used the daily number of hours surveyed at Beaufort sea state $<4$ (Hooker et al. 2002, Brown et al. 2007) as our measure of effort. Results are reported as variation in whale encounter rate $(E R$, number of right whale encounters/number of hours of effort) among survey days, years and defined regions (following Hooker et al. 2002).

\subsection{Temporal right whale occurrence descriptors}

Measures of temporal variability in right whale occurrence were developed using data collected within the GMB domain $\left(44^{\circ} 27^{\prime}\right.$ to $44^{\circ} 46^{\prime} \mathrm{N}, 66^{\circ} 20^{\prime}$ to $\left.66^{\circ} 37^{\prime} \mathrm{W}\right)$ which defines the region where $>90 \%$ of right whale sightings and effort occurred each year (Fig. 1). The chosen domain approximately encompassed bathymetry >150 m where right whale food aggregates, which is presumably the main factor driving the variability in right whale occurrence in the habitat (Michaud \& Taggart 2011).

Annual and seasonal right whale habitat occurrence was quantified through analyses of sightings per unit effort and number of photo-identified individuals. From these data, 8 annual metrics of occurrence in the habitat were generated using only the August and September data (Table 1). The first 2 metrics were total number of individually identified whales (N) and \% of survey days when whales were not encountered $(\%$
Fig. 1. Positions of encounters with North Atlantic right whales Eubalaena glacialis (grey dots) are shown in relation to the Grand Manan Basin critical habitat boundary (dashed line) and Bay of Fundy Traffic Separation Scheme (Fundy TSS; solid black lines). Inset: location of the study area relative to the Maritimes Provinces in eastern Canada 
Table 1. Right whale Eubalaena glacialis occurrence descriptors used in this study

\begin{tabular}{|c|c|c|c|c|c|}
\hline Descriptor & Acronym & Units & Datasets & Descriptor type & Explanation \\
\hline $\begin{array}{l}\text { No. of unique photo- } \\
\text { identified individuals }\end{array}$ & $\mathrm{N}$ & Whales & Photo-ID & $\begin{array}{l}\text { Abundance (not } \\
\text { effort corrected) }\end{array}$ & $\begin{array}{l}\text { Annual total number of individuals sighted in } \\
\text { the habitat during all survey days }\end{array}$ \\
\hline$\%$ Absence & & $\%$ & Sightings, Effort & Presence/absence & $\begin{array}{l}\text { Annual number of survey days when zero right } \\
\text { whales were sighted as a percentage of total } \\
\text { survey days }\end{array}$ \\
\hline $\begin{array}{l}\text { Annual integrated } \\
\text { encounter rate }\end{array}$ & IER & $\begin{array}{l}\text { Whale } \\
\text { days }\end{array}$ & $\begin{array}{l}\text { Sightings, Effort, } \\
\text { Photo-ID }\end{array}$ & Total occurrence & Annual index of total encounters with whales \\
\hline Daily encounter rate & ER & No. $h^{-1}$ & $\begin{array}{l}\text { Sightings, Effort, } \\
\text { Photo-ID }\end{array}$ & Density & $\begin{array}{l}\text { Daily number of individual whales sighted (no } \\
\text { repeats) divided by the number of hours of } \\
\text { survey effort }\end{array}$ \\
\hline $\begin{array}{l}\text { Monthly anomaly of } \\
\text { encounter rate }\end{array}$ & MAER & No. $h^{-1}$ & $\begin{array}{l}\text { Sightings, Effort, } \\
\text { Photo-ID }\end{array}$ & $\begin{array}{l}\text { Seasonal variation } \\
\text { in density }\end{array}$ & $\begin{array}{l}\text { Difference between monthly mean ER } \\
\text { (August-September) }\end{array}$ \\
\hline $\begin{array}{l}\text { Power function } \\
\text { exponent }\end{array}$ & PFE & & Photo-ID, Effort & Time of arrival & $\begin{array}{l}\text { Exponent of the power function that describes } \\
\text { the annual discovery curve of newly sighted } \\
\text { individuals }\end{array}$ \\
\hline $\begin{array}{l}\text { New individual } \\
\text { encounter rate_0-10h }\end{array}$ & NIER_0-10 & No. $h^{-1}$ & Photo-ID, Effort & Time of arrival & $\begin{array}{l}\text { Linear slope of the discovery curve between } 0 \\
\text { and } 10 \mathrm{~h} \text { of effort, which approximates the } \\
\text { encounter rate of new individuals in the habitat } \\
\text { at the beginning of the survey year }\end{array}$ \\
\hline $\begin{array}{l}\text { New individual } \\
\text { encounter rate_70- } \\
80 \mathrm{~h}\end{array}$ & NIER_70-80 & No. $h^{-1}$ & Photo-ID, Effort & Time of arrival & $\begin{array}{l}\text { Linear slope of the discovery curve between } 70 \\
\text { and } 80 \mathrm{~h} \text { of effort, which approximates the } \\
\text { encounter rate of new individuals in the habitat } \\
\text { near the end of the survey year }\end{array}$ \\
\hline Area of occurrence & $\mathrm{AOO}$ & $\mathrm{Km}^{2}$ & Sightings, Effort & Distribution & $\begin{array}{l}\text { Area encompassing all } 2 \times 2 \text { min grid cells } \\
\text { where sightings exceeded zero }\end{array}$ \\
\hline
\end{tabular}

absence). Average daily encounter rate (ER) approximated the relative density of unique individuals (i.e. excluding re-sightings of the same individual) in the habitat each day. Time series of average ER, expressed as an annual anomaly relative to the grand median, were generated for each month and year, and the difference in ER between monthly series (monthly anomaly of ER or MAER, no. $\mathrm{h}^{-1}$ ) was used to characterize annual variation in monthly whale density.

The annual integrated ER (IER, whale days) was modeled using the daily ER data. First the $\log _{10}$-transformed ER data were fit using a restricted least squares cubic spline with 4 equidistant knots (Harrell 2001, Fig. S1a in the Supplement at www.int-res.com/articles/suppl/ n039p159_supp.pdf). This interpolation captured the seasonal trend in encounter rates each year. IER and its associated error were then derived by integrating the model function $\pm 95 \%$ CI generated by bootstrapping with 1000 resamples) over time following Eq. (1)

$$
\mathrm{IER}=\sum_{t}^{d=1} \sum_{24}^{h=1} \mathrm{ME}_{d}
$$

where ME is modeled daily encounter rate, $d$ is day of year, $t$ is final survey day, and $h$ is hour of day between 1 and 24 (Fig. S1b). Integrating under the spline curve resulted in an occurrence metric that was comparable among years with heterogeneous sampling effort and temporally variable patterns in whale density (Fig. S2).

The advantage of these right whale data accrues because survey teams attempt to photo-identify nearly every individual they sight during a survey day. For each annual survey, the relation between cumulative first sighting of each individual that year and cumulative survey effort (annual 'discovery curve') can be described using a power function ( $y=$ $a x^{b}$ ) where the parameters contain information about the time of arrival of individuals (Fig. 2). The exponent $b<1$ indicates most individuals immigrate into the habitat for the first time early in the survey year. If the immigration of new animals primarily occurs early in the year, then as the survey season progresses, all animals are eventually sighted, resulting in a discovery curve approaching an asymptote with increasing survey effort. The exponent $b=1$ 


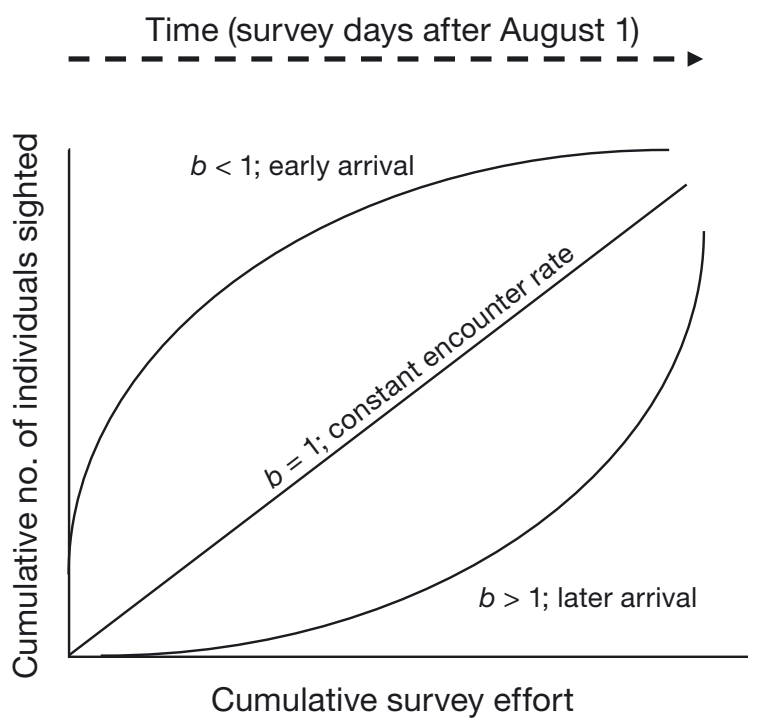

Fig. 2. Conceptual diagram relating the power curve exponent $(b)$ to time of arrival of new individual migratory animals into a habitat. In this study, 'new individual' refers to the first sighting of an individual in a survey year

indicates a relatively constant immigration of new individuals into the habitat throughout the survey season, whereas $b>1$ indicates a delayed arrival of the population. We use this conceptual model to compare annual and decadal variation in the timing of occurrence (see Fig. S3 for examples of model fit to real data). This measure does not estimate the total immigration rate as it ignores re-immigration of the same individuals (which does occur; Brillant et al. 2015). It is nonetheless useful as a first approximation of arrival time, especially when considered in combination with measures of relative whale density.

Three parameters of the discovery curves were used to characterize effort-corrected variation in the occurrence of newly sighted individuals. First, the power function exponent (PFE) was calculated for each annual discovery curve and interpreted as described in Fig. 2. In addition to the PFE, encounter rate estimates at discrete time steps along the discovery curve were used to characterize the encounter rate at effort-time. Therefore, the linear slope of the discovery curve at 2 effort-time intervals was calculated to estimate new individual encounter rate (NIER) at the beginning (0-10 effort-hours, NIER 0-10) and toward the end (70-80 effort-hours, NIER_ $70-80$ ) of the survey season. The 70-80 h criterion was dictated by the years with the least effort (71 and 73 h during 2013 and 2015, respectively). Early arrival of the population should result in a higher encounter rate at the $0-10 \mathrm{~h}$ interval, and vice versa for the later arrival.
Principal components analysis (PCA) was used to examine variation within and among the 8 occurrence descriptors. The goal was to quantify the most important modes of variability in the multivariate space (principal axes; PC), and to determine if years were partitioned among periods with similar occurrence patterns based on PC scores (i.e. Euclidean distance) among years. Data were centered and standardized ( $z$-score) to make the data dimensionally homogeneous, and the PCA was performed on the dispersion matrix. Zero-inflated variables can lead to incorrect Euclidean distance estimates among years (Legendre \& Legendre 2012), therefore the analysis was conducted with and without the '\% Absence' variable which contained zeroes in 13 of $30 \mathrm{yr}$. However, this did not change the results. The model was evaluated using $\mathrm{r}^{2}$ on each PC, and only PCs with eigenvalue $\lambda>1$ (Keiser-Guttman criterion) were interpreted. The contribution of each variable to the reduced space was evaluated using the equilibrium circle (Legendre \& Legendre 2012) and only variables that contributed significantly to each PC are discussed.

\subsection{Spatial analysis of right whale encounters}

The Bay of Fundy was divided into 3 regions (irregular polygons) to quantify decadal-scale differences in space-use within and outside the critical habitat $(\mathrm{CH})$. Effort outside the $\mathrm{CH}$ boundary is not equally distributed across the Bay, rather it is concentrated to the NW where survey vessels typically transit daily to and from the New Brunswick coast (hereafter denoted Owen Basin-The Wolves after charted regional landmarks, abbreviated to OBTW), and SE of the $\mathrm{CH}$ in the Bay of Fundy Traffic Separation Scheme (shipping lanes, hereafter TSS, Fig. S4). Therefore, the 3 regions were defined by the $\mathrm{CH}$ boundary, a boundary that extends the NW and NE $\mathrm{CH}$ boundaries to the edge of the study domain, and a boundary extending from the SE half of the $\mathrm{CH}$ boundary to the southern- and westernmost TSS waypoints (Fig. S4). These 3 regions, $\mathrm{CH}, \mathrm{OBTW}$, and TSS, contain $55.7,29.5$ and $7.9 \%$ of the total survey effort, respectively.

Whale count (number of whales estimated by the survey team on the water, regardless of identification) and effort (h) were each aggregated over each year and each region. Whale count and effort were divided to produce estimates of gross encounter rate $\left(\right.$ no. $\left.\mathrm{h}^{-1}\right)$. Area of right whale occupancy (AOO) within each region was then approximated by the 
area encompassing all $2 \times 2$ min grid cells where sightings exceeded zero in a survey year (Table 1 ). This measure and the average encounter rate calculated within each regional area of occupancy were together used to determine whether variability in occurrence may be due to distributional expansion or contraction, animal density, or both. For statistical analysis, 4 multi-annual periods were delineated based on the outcome of the PCA analysis (see PCA results in Section 3.1): 1987-1991, 1992-2000, 2001-2009 and 2010-2016. ANOVA was then used to assess differences in square-route transformed ER among region and multi-annual period.

\section{RESULTS}

\subsection{Temporal variation in occurrence}

Encounters with right whales in the GMB varied by 2 orders of magnitude among years with a pronounced decline starting near 2010 (Fig. 3a,b, Table S1). Low encounter rates during 2010-2015 cooccurred with a high number of days when whales were absent (zero sightings). Prior to 2010, zero sightings on a survey day occurred infrequently, dur- ing less than $50 \%$ of the years, and in years when they did occur the absences averaged 10\% (range $4-31 \%$ ) of survey days (Fig. 3a). From 2010-2015 absences increased to an average of approximately $44 \%$ (range $6-91 \%$ ) of survey days. Time-integrated encounter rate (IER; whale days \pm SD) was generally below average during 1987-1991 (371 + 116), above average during 1992-2009 (638 \pm 176) and well below average during 2010-2016 (183 \pm 158). IER was significantly lower during 2010-2016 than the previous 18 yr (Mann-Whitney $U, \mathrm{p}<0.0001$ ).

Decadal variation was also evident in the seasonal occupancy variables (Fig. 4a). Prior to 2002, right whale encounter rate was, on average, fairly equal between August and September (MAER $=-0.002 \pm$ 0.11), whereas from 2002 through 2010 encounter rate was higher in September than August (MAER = $-0.11 \pm 0.08$; Mann-Whitney $U, p=0.027$ ). From 2005 through 2015, MAER increased linearly as occurrence again gradually advanced to earlier in the season. Concurrently, the power function exponent of the discovery curve was smaller before 2002 than after 2002 with an average PFE of 0.52 vs. 0.89, respectively (Mann-Whitney $U, \mathrm{p}=0.002$, Fig. 4b). From 1987 through 2001, encounter rate of newly sighted individuals during the first day or 2 of the survey season
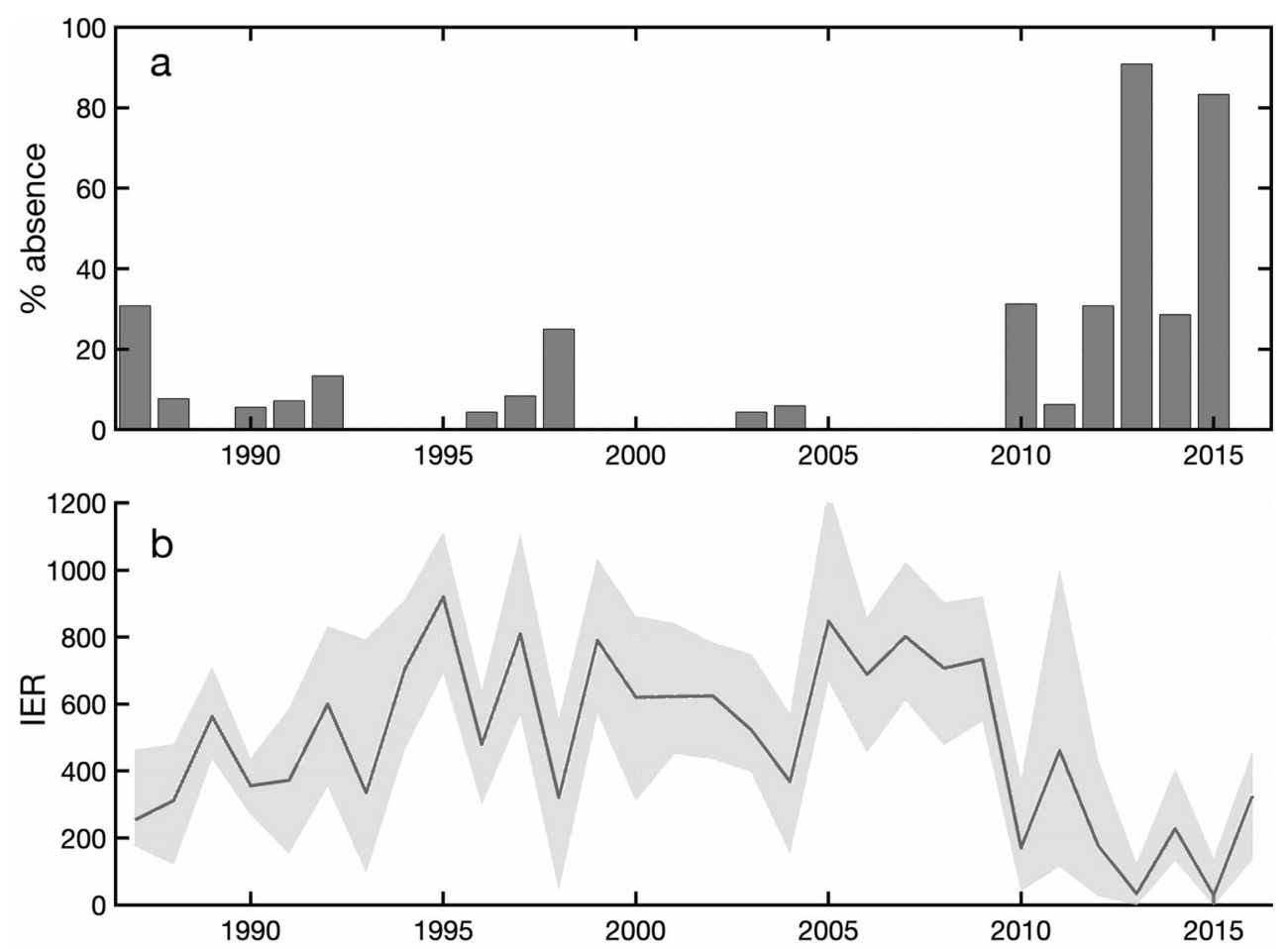

Fig. 3. Time series of right whale annual habitat occurrence descriptors in the Bay of Fundy during $1987-2016$ (see Table 1 for descriptor definitions). (a) Percentage of survey days each year when zero right whales were sighted. (b) Annual integrated encounter rate (IER; whale days $\pm 95 \%$ CI [gray shading]) 

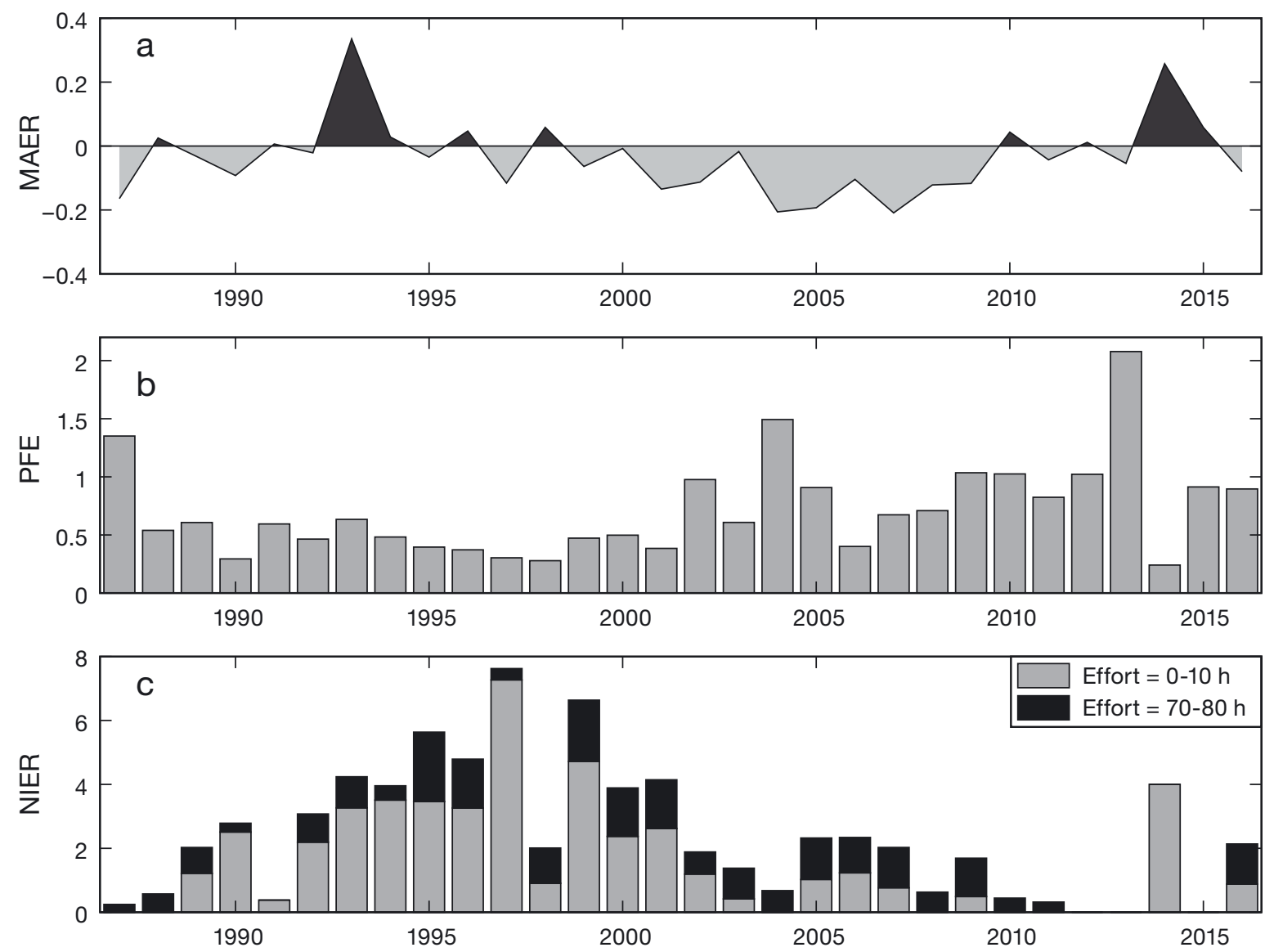

Fig. 4. Time series of right whale seasonal habitat occurrence descriptors in the Bay of Fundy during 1987-2016 (see Table 1 for descriptor definitions). (a) Monthly anomaly of encounter rate (MAER, $\mathrm{h}^{-1}$ ) where positive values (black) indicate higher rates in August and negative values (grey) depict higher rates in September. (b) Exponent of the power function (PFE) fit to the annual discovery curve of newly sighted individuals by cumulative survey effort, where higher PFE values indicate later arrival of individuals into the habitat. (c) New individual encounter rate (NIER, $\mathrm{h}^{-1}$ ) measured at 2 time steps on the discovery curves: $0-10 \mathrm{~h}$ (gray) and 70-80 h (black). Two additional indices, daily encounter rate (ER) and total number of photo-identified individuals (N) were not included in the figure for brevity because they were highly correlated with IER (Fig. 3b)

$(0-10 \mathrm{~h})$ increased from 0 to a maximum of $7 \mathrm{~h}^{-1}$ survey effort (Fig. 4c). This rate then declined after 2001 (Mann-Whitney $U, \mathrm{p}=0.0048$ ), reaching a minimum of no animals sighted in the first $10 \mathrm{~h}$ of survey effort every year from 2010 through 2015, except in 2014.

The variance along PC1 $\left(\mathrm{r}^{2}=0.58, \lambda=4.7\right)$ was explained by the abundance descriptors $\mathrm{N}, \mathrm{ER}$, IER and $\%$ absence, whereas the variance along PC2 $\left(\mathrm{r}^{2}=\right.$ $0.14, \lambda=1.4$ ) was explained by 3 seasonal occurrence descriptors PFE, NIER_0-10 and MAER (Fig. 5a). NIER_70-80 was not an important contributing descriptor along either PC1 or PC2, likely because the variance among years was small (Fig. 4c). Positive PC1 scores indicated greater abundance or density, while negative scores indicated lower abundance and a greater proportion of days when whales were not sighted. The eigenvectors were similar in length among descriptors, indicating they contributed simi- larly to the formation of the axis. The first PC mode (Fig. 5b) captured a long-term parabolic trend in abundance, including a sharp decline starting in 2010 that is evident in the IER series. A decadal-scale change in monthly occurrence between the periods of 1987 through 2001 and 2002 through 2014 was the most important mode along PC2 (Fig. 5c).

The clustering of year-scores along the first 2 PCs was not strong, indicating that transitions among occurrence states were gradual rather than step-like, which is evident in most of the time series illustrated in Figs. 3 \& 4. However, there was weak division of the data among the 4 PC quadrants in Fig. 5b,c into 4 states: 1987-1991 (low abundance, late arrival); 1992-2000 (high abundance, early arrival); 20012009 (high abundance, late arrival); 2010-2016 (low abundance, variable arrival). Monthly (July, August, September and October) encounter rate was gener- 

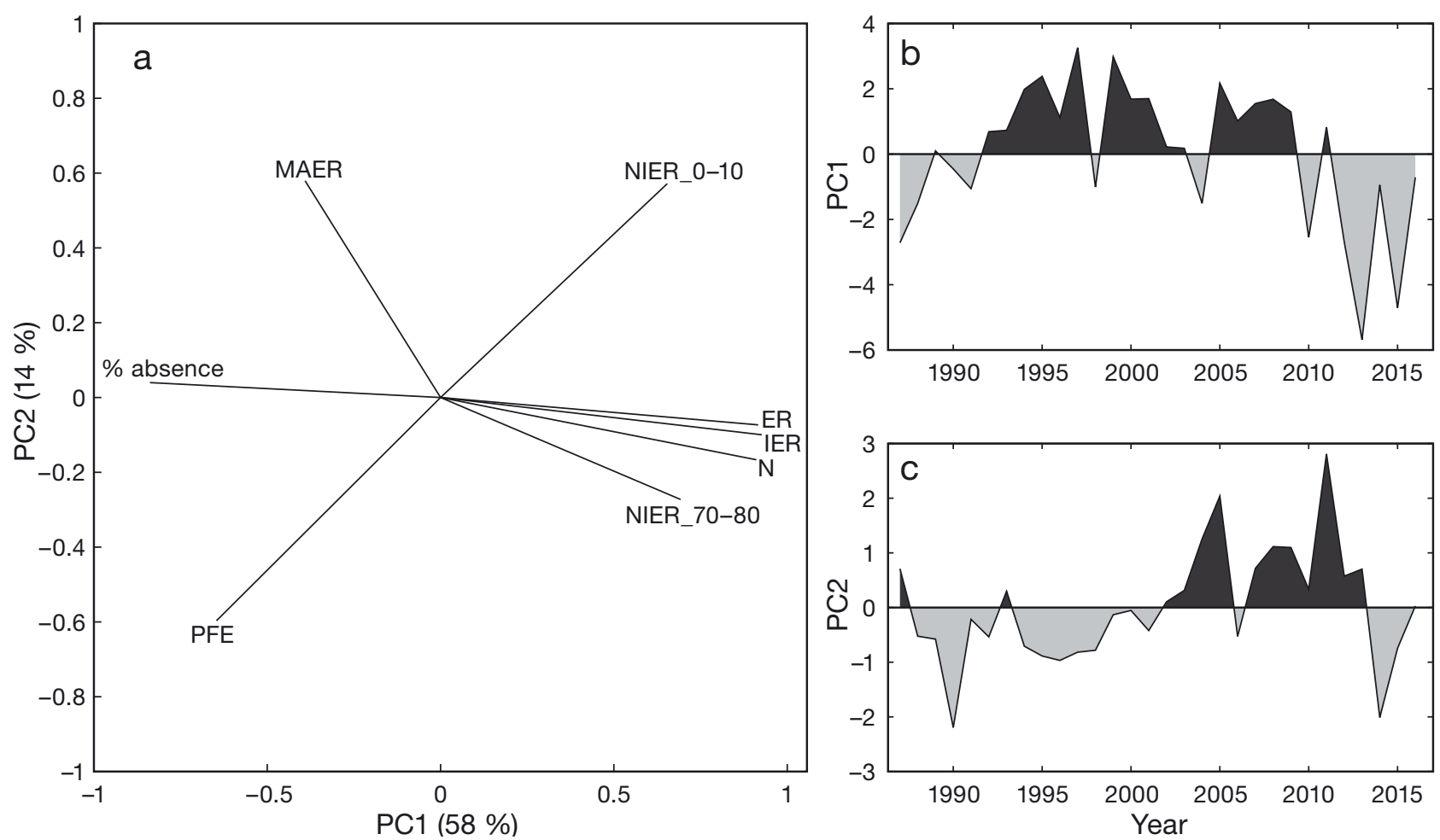

Fig. 5. Principal components (PC) analysis of 8 right whale occurrence descriptors (see Table 1 for descriptor definitions). (a) Correlation biplot where smaller angles between the vectors of each descriptor (labeled) indicate larger correlations between descriptors, and the angle of each descriptor to each principal axis (PC) indicates its contribution to that axis. (b,c) Time series of year scores along (b) PC1 and (c) PC2 showing the 2 most important modes of temporal variability in the dataset. Shading highlights positive (black) and negative (gray) PC scores. PC1 explains $58 \%$ of the variation in the original data, while PC 2 explains $14 \%$

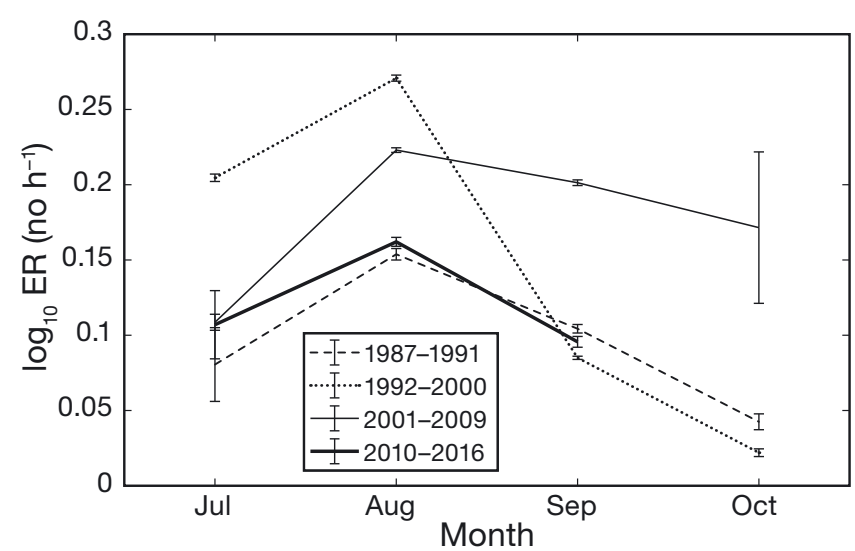

Fig. 6. Monthly variability in daily mean right whale encounter rates $\left(E R\right.$, no. $\left.\mathrm{h}^{-1} \pm 1 \mathrm{SE}\right)$ among 4 multi-annual time periods. No data were collected in October during the 2010-2016 period

ated for each of these 4 periods to further assess variability in arrival time (Fig. 6). Aggregating data over multi-year periods was required to examine July and October due to sparse survey data in those months (Fig. S4). Significant differences in daily encounter rate were found among months and multi-year peri- ods (significant interaction term in an ANOVA, Table S2). Notably, encounters were anomalously high during July and low in October 1992-2000 (Tukey post-hoc, $\mathrm{p}<0.05$ ). This pattern inverted in the subsequent $8 \mathrm{yr}$, when encounters were higher in October and lower in July (Tukey post-hoc, $\mathrm{p}<0.05$ ). These results are consistent with the PCA findings, providing further evidence of a strong seasonal shift in occupancy before and after the year 2000.

\subsection{Spatial variation in occurrence}

Multi-year changes in 2 measures, average ER and area of occupancy (AOO), varied among the 3 regions in the Bay of Fundy (interaction terms significant, Table S2). There were no differences in either measure between the 1992-2000 and 2001-2009 periods, so the data in those 2 time periods were aggregated in further analyses (Table 2). Both measures were higher in the $\mathrm{CH}$ than the other 2 areas in all decades (Table 2). Annual ERs in the $\mathrm{CH}$ were lower during 1987-1991 and 2010-2016 than in the intervening years (Bonferroni post-hoc test, $\mathrm{p}<0.05$ ), whereas 
Table 2. Statistics on historical right whale occurrence in 3 regions of the Bay of Fundy (see Fig. S4 for region map). Area of occupancy $\left(\mathrm{km}^{2}, \%\right.$ of available area) is approximated by all 2 min squared gridcells for which 1 or more right whale sightings occurred within a region and year. Mean $\left( \pm \mathrm{SD}\right.$, no. $\left.\mathrm{h}^{-1}\right)$ and aggregate $\left(\right.$ no. $\left.\mathrm{h}^{-1}\right)$ encounter rates are calculated across grid cells $(\mathrm{A})$ within each region or $(\mathrm{B}, \mathrm{C})$ regional area of occupancy. Columns (rows) superscripted with the same letter (number) are not significantly different (Bonferroni post-hoc analysis, bold $\alpha=0.1$, not bold $\alpha=0.05$ )

\begin{tabular}{|c|c|c|c|}
\hline & $\begin{array}{l}\text { Critical } \\
\text { habitat } \\
\left(744 \mathrm{~km}^{2}\right)\end{array}$ & $\begin{array}{c}\text { Traffic separation } \\
\text { scheme } \\
\left(933 \mathrm{~km}^{2}\right)\end{array}$ & $\begin{array}{l}\text { Owen Basin- } \\
\text { The Wolves } \\
\left(1967 \mathrm{~km}^{2}\right)\end{array}$ \\
\hline \multicolumn{4}{|c|}{ A. Mean encounter rate; no. $\mathrm{h}^{-1}(\mathrm{SD})$} \\
\hline $1987-1991$ & $1.40(0.77)^{\mathrm{a}, 1}$ & $0.66(0.59)^{\mathrm{a}, 2}$ & $0.01(0.02)^{\mathbf{a}, 3}$ \\
\hline 1992-2009 & $2.97(0.98)^{\mathrm{b}, 1}$ & $0.74(0.63)^{\mathrm{a}, 2}$ & $0.17(0.22)^{\mathbf{a}, 3}$ \\
\hline 2010-2016 & $1.02(0.85)^{\mathrm{a}, 1}$ & $0.17(0.36)^{\mathrm{a}, 2}$ & $0.24(0.31)^{\mathbf{b}, 2}$ \\
\hline \multicolumn{4}{|c|}{ B. Area of occupancy; $\mathrm{km}^{2}$ (SD) } \\
\hline $1987-1991$ & $306(108)^{a, 1}$ & $47(36)^{\mathrm{a}, 2}$ & $5(9)^{\mathbf{a}, 2}$ \\
\hline 1992-2009 & $462(85)^{a, 1}$ & $61(52)^{\mathrm{a}, 2}$ & $49(53)^{\mathbf{a}_{2} 2}$ \\
\hline $2010-2016$ & $248(161)^{\mathrm{a}, 1}$ & $16(26)^{\mathrm{a}, 2}$ & $75(83)^{\mathbf{b}, 2}$ \\
\hline \multicolumn{4}{|c|}{ C. Mean encounter rate within the area of occupancy; no. $\mathrm{h}^{-1}(\mathrm{SD})$} \\
\hline $1987-1991$ & $1.87(0.78)$ & $2.42(1.20)$ & $1.78(1.80)$ \\
\hline 1992-2009 & $3.26(1.00)$ & $2.42(1.33)$ & $2.41(2.55)$ \\
\hline 2010-2016 & $1.66(0.65)$ & $1.34(1.10)$ & $1.23(0.72)$ \\
\hline
\end{tabular}

viduals throughout the survey season, indicating that a few animals trickled into the habitat over the season and departed soon after, since the habitat typically failed to maintain moderate whale densities for longer than a few days at a time. These findings are consistent with visual observations by right whale monitoring teams in the nearby Gulf of Maine (NARWC 2015, 2017), and a recent publication by Davis et al. (2017) that showed summertime right whale acoustic detections collected during 2011-2014 declined in the Gulf of Maine compared to the previous 7 yr. Concurrently, right whale detections have increased in at least 3 alternate locations: Cape Cod Bay (Mayo et al. 2018), the mid-Atlantic Bight (Davis et al. 2017) and the Gulf of St. Lawrence. Sighting increases in the Gulf of St. Lawrence since 2015 are at least partly due to increased survey effort in that region, although the Mingan Island Cetacean Study, operating in the Jacques Cartier Passage since 1979, has noted increased presence of right whales during their surveys which sugboth the $\mathrm{AOO}$ and average encounter rate within the area of occurrence (MEAOO) were stable over time (Table 2). Average values of both ER and AOO were approximately 3- to 4-fold lower in the TSS during 2010 through 2016, though this was not significant due to high inter-annual variability (Table 2). In contrast, there was some evidence that occurrence within the OBTW may be increasing, primarily due to distributional expansion, as the AOO is now significantly larger than in any previous period at the $\alpha=0.1$ level (Table 2). No regional differences in MEAOO were found (Table S2), again due to high distributional variability among years.

\section{DISCUSSION}

This study demonstrates there has been an effortindependent decline in right whale occurrence during the summer months in the Bay of Fundy beginning in 2010. This multi-year habitat shift is unique compared to the previous $24 \mathrm{yr}$. While low abundance has occurred in previous years, especially during the late 1980s to early 1990s, the recent decline since 2010 is unique and marked by extended periods (up to $44 \%$ of survey days) when no whales were sighted in the $\mathrm{CH}$. This period is further marked by a low and relatively constant immigration of new indi- gests whales have been using the region more often in recent years. These patterns strongly suggest that climate-scale changes in food supply have occurred and are driving a population- and feeding rangewide shift in right whale habitat usage. While such shifts have occurred in recent history (Kenney 2001, Greene et al. 2008, 2013, Davies et al. 2015b, MeyerGutbrod et al. 2015, Meyer-Gutbrod \& Greene 2018), never since records began has occurrence in the Bay of Fundy been so low, implying that the current conditions may be driven by heretofore undiagnosed processes.

Habitat shifts are a much greater source of local variability in right whale occurrence than population dynamics over decadal time scales, and the population growth rate is so small and sensitive to these shifts that their impact on the population can quickly become apparent. During 1990-2010, the number of right whales available to be identified (population size) increased at $2.8 \% \mathrm{yr}^{-1}$ on average such that there were an estimated 270 animals in 1990 and 483 in 2010 (Pace et al. 2017). Occurrence in the Bay of Fundy increased nearly 4-fold (from median 37 to 137 individuals sighted annually) during 1992-2000 relative to the previous decade, primarily due to a shift in use away from Roseway Basin (Davies et al. 2015a). Similarly, occurrence declined 3-fold during 2010-2015 compared to the previous decade, whereas 
Pace et al. (2017) suggest the population was declining by just $1 \% \mathrm{yr}^{-1}$ over the same period. Occurrence in Cape Cod Bay has also increased significantly during this period at a rate higher than population size (Mayo et al. 2018), which is consistent with our finding that habitat shifts are the primary driver of changes in local occurrence in this species. These habitat shifts, which have been linked to changing food resources, influence population dynamics through impacts on calving success (Meyer-Gutbrod et al. 2015) and mortality rates (Meyer-Gutbrod et al. 2018), and are therefore critically important to both quantify and explain.

The multivariate analysis approach was valuable for quantifying dominant modes of variability in whale occurrence. The analysis unexpectedly revealed a decadal mode in seasonal timing of occurrence that was orthogonal to the variation in total annual abundance. Discovery curve measures, which have not been used before to describe interannual variability in right whale occurrence, were important in demonstrating the decadal-scale change in the seasonal timing of occurrence along this second mode. Model results suggest that during the 1990s new individuals usually immigrated into the GMB early in the summer (July or earlier), and accumulated in high densities by 1 August. In the 2000s, right whales immigrated into the GMB later in the summer (after 1 August, as indicated by increased PFE), and did not accumulate into high densities until September. This is the simplest explanation for the change in the character of the discovery curve from asymptotic to linear, post-2001, which was driven primarily by a decline in sightings of new individuals at the beginning of the survey season (NIER_0-10). Since 2014, the animals appear to have been arriving earlier again, yet not staying resident in the GMB in most of these recent years. Historical sightings and acoustic records indicate that the period of right whale occurrence in Canadian waters can be May through December at least, corresponding with the known canonical period of peak abundance of Calanus finmarchicus stage-C5 (Mellinger et al. 2007, Michaud \& Taggart 2011, Brillant et al. 2015, Fisheries and Oceans Canada 2018). Our finding highlights the potential for right whales to occur in high numbers outside of the regular survey period of August and September for many years at a time. Expansion or re-allocation of survey effort across a broader time span may increase the likelihood of encountering these animals.

The seasonal timing of $C$. finmarchicus abundance is most likely the primary driver explaining the decadal variation in right whale occurrence we ob- served, but the mechanisms that have caused prey to change in the Bay of Fundy remain unclear. At Prince 5 station in the outer Bay of Fundy, mesozooplankton is monitored monthly using depth-integrated nettows, and those data show a significant seasonal shift in the timing of high abundances of $C$. finmarchicus from autumn and winter during 1999-2008 to spring and early summer during 2009-2015 (Fig. 7, MannWhitney $U, p=0.001$ ). Local changes in phenology of Calanus productivity may cause this pattern and explain recent changes in right whale occurrence. Alternatively, right whales may arrive earlier in the Bay of Fundy because food sources in the Great South Channel, a critical spring feeding area, are also in decline, causing right whales to move northward along their migration route earlier in the year. In addition to high background concentrations of Calanus spp., right whales require food to be aggregated into high concentrations and energy densities to facilitate efficient foraging (Kenney et al. 1986, Baumgartner \& Mate 2003, Michaud \& Taggart 2011, Davies et al. 2014). Diapause causes C5s to cease diel-vertical migration and remain at depth below the pycnocline until emergence in winter (Johnson et al. 2008). This process creates vertically aggregated C5 layers at depth, especially in basins or channels where local currents can rapidly accumulate the animals into high concentration patches both vertically and laterally (Michaud \& Taggart 2011, Davies et al. 2013, 2014). The outer Bay of Fundy gyre in the GMB retains particles in the deep water of the Basin during

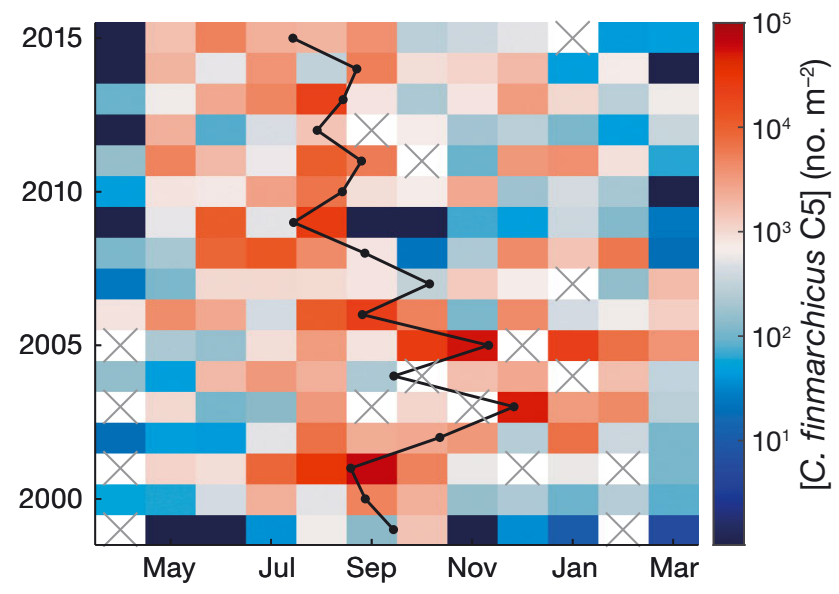

Fig. 7. Time series of monthly and annual depth-integrated ( 0 to $95 \mathrm{~m}$ ) concentration of Calanus finmarchicus stage-C5 abundance $\left(\mathrm{m}^{-2}\right)$ at Prince 5 station in the Bay of Fundy color-scaled according to anomaly relative to the grand mean (+ red, - blue), and abundance-weighted mean sampling month (black line) plotted to illustrate annual changes to the seasonal timing of peak abundance. Boxes containing a cross show months when no sample was collected 
the summer period because baroclinically driven retention increases during the stratified season (Aretxabaleta et al. 2008, 2009), and the gyre is probably a major driver of high C5 abundances at depth in that habitat. The timing of both diapause initiation and physical accumulation processes may thus constrain the temporal window of the peak right whale feeding period to the summer period regardless of changes in productivity and supply. Mismatches between productivity of Calanus and the timing of aggregation processes could significantly affect habitat suitability and perhaps help explain the recent absence of whales from the Basin habitat. This analysis confirms that inter-annual variability in right whale occurrence in the Bay of Fundy is strongly driven by processes affecting food supply in the GMB CH. Additionally, there is some evidence that the animals remaining in the area may be shifting their distribution north west into shallower water, which may be cause for conservation concern if this distribution shift results in increased co-occurrence with the suite of contemporary threats that impact right whales including vessel strikes, fisheries interactions and anthropogenic noise.

The extent to which other habitats in or outside the Bay of Fundy may provide a foraging refuge during times of low productivity in the $\mathrm{CH}$ has yet to be investigated, but the prospects appeared minimal during the 2010-2016 period. Of all zooplankton stations monitored annually from the Cabot Strait to the Bay of Fundy, Prince 5 station was the only place for which the $C$. finmarchicus abundance anomaly during 2010-2015 was average or only slightly below average (Johnson et al. 2017). In contrast, C. finmarchicus abundance at stations in the Cabot Strait and the eastern, western and central Scotian Shelf have each seen much stronger negative anomalies in most years, including at Halifax Line Station 2 which is sampled bi-weekly (Johnson et al. 2017). Further, the arctic Calanus species $C$. hyperboreus and $C$. glacialis have experienced negative anomalies. Large numbers of right whales have been sighted presumably foraging in more northerly regions (i.e. Gulf of St. Lawrence), which may be providing some refuge. The continued decline in reproductive rates suggests that right whales continue to suffer from lack of food availability throughout most of their feeding range; however, a lag of several years between improvements in food supply and calving is possible since females require time to accumulate reserves, mate and carry a pregnancy to term. Future research into the phenology of food supply, and particularly that pertaining to the accumulation of lipids and its impact on this phenology across the Gulf of Maine, Scotian Shelf and Gulf of St. Lawrence regions, is essential to address the causes and consequences of the temporal and spatial shift in habitat use by right whales.

Acknowledgements. We thank the crews of the North Atlantic right whale annual monitoring surveys in the Bay of Fundy and the supporting organizations New England Aquarium and Canadian Whale Institute for efforts to maintain the time series in that habitat. We are grateful to the numerous volunteers who contributed right whale sightings data to the database over the years, particularly Brier Island Whale and Seabird Cruises, Quoddy Line Marine and Laurie Murison. Thank you to Monica Zani for seasonal database management and to Philip Hamilton and Robert Kenney for maintaining the right whale databases and handling the database access request for this study. Thank you to the Atlantic Zone Monitoring Program for collecting the environmental data, and particularly Benoit Casault, Roger Pettipas and Catherine Johnson at Fisheries and Oceans Canada for handling the environmental data access request. We thank D. Pendleton and 4 anonymous referees for advice, critiques and assistance. Right whale research was conducted under annual permits issued by the Department of Fisheries and Oceans Canada. Funding to K.T.A.D. to conduct this study was provided by the Liber Ero Fellowship Program and Marine Environmental Observation, Prediction and Response Tri-Council Network of Centres of Excellence.

\section{LITERATURE CITED}

Aretxabaleta AL, McGillicuddy DJ, Smith KW, Lynch DR (2008) Model simulations of the Bay of Fundy Gyre: 1. Climatological results. J Geophys Res 113:C10027

Aretxabaleta AL, McGillicuddy DJ, Smith KW, Manning JP, Lynch DR (2009) Model simulations of the Bay of Fundy Gyre: 2. Hindcasts for 2005-2007 reveal interannual variability in retentiveness. J Geophys Res 114:C09005

* Baumgartner MF, Mate BR (2003) Summertime foraging ecology of North Atlantic right whales. Mar Ecol Prog Ser 264:123-135

* Baumgartner MF, Mate BR (2005) Summer and fall habitat of North Atlantic right whales (Eubalaena glacialis) inferred from satellite telemetry. Can J Fish Aquat Sci 62: $527-543$

* Baumgartner MF, Cole TVN, Clapham PJ, Mate BR (2003) North Atlantic right whale habitat in the lower Bay of Fundy and on the SW Scotian Shelf during 1999-2001. Mar Ecol Prog Ser 264:137-154

* Brillant SW, Vanderlaan ASM, Rangeley RW, Taggart CT (2015) Quantitative estimates of the movement and distribution of North Atlantic right whales along the northeast coast of North America. Endang Species Res 27:141-154

Brown M, Kraus S, Slay C, Garrison L (2007) Surveying for discovery, science and management. In: Kraus SD, Rolland RM (eds) The urban whale: North Atlantic right whale at the crossroads. Harvard University Press, Cambridge, MA, p 105-137

Brown MW, Fenton D, Smedbol RK, Merriman C, RobichaudLeblanc K, Conway JD (2009) Recovery strategy for the 
North Atlantic right whale (Eubalaena glacialis) in Atlantic Canadian waters [Final]. Species at Risk Act Recovery Strategy Series. Fisheries and Oceans Canada, Ottawa

Campbell RG, Wagner MM, Teegarden GJ, Boudreau CA, Durbin EG (2001) Growth and development rates of the copepod Calanus finmarchicus reared in the laboratory. Mar Ecol Prog Ser 221:161-183

* Chivers WJ, Walne AW, Hays GC (2017) Mismatch between marine plankton range movements and the velocity of climate change. Nat Commun 8:14434

Daoust PY, Couture EL, Wimmer T, Bourque L (2017) Incident report: North Atlantic right whale mortality event in the Gulf of St. Lawrence, 2017. Collaborative report produced by Canadian Wildlife Health Cooperative, Marine Animal Response Society, and Fisheries and Oceans Canada

Navies KTA, Ross T, Taggart CT (2013) Tidal and subtidal currents affect deep aggregations of right whale prey, Calanus spp., along a shelf-basin margin. Mar Ecol Prog Ser 479:263-282

Wavies KTA, Taggart CT, Smedbol RK (2014) Water mass structure defines the diapausing copepod distribution in a right whale habitat on the Scotian Shelf. Mar Ecol Prog Ser 497:69-85

Davies KTA, Taggart CT, Smedbol RK (2015a) Interannual variation in diapausing copepods and associated water masses in a continental shelf basin, and implications for copepod buoyancy. J Mar Syst 151:35-46

WDavies KTA, Vanderlaan ASM, Smedbol RK, Taggart CT (2015b) Oceanographic connectivity between right whale critical habitats in Canada and its influence on whale abundance indices during 1987-2009. J Mar Syst 150:80-90

Navis GE, Baumgartner MF, Bonnell JM, Bell J and others (2017) Long-term passive acoustic recordings track the changing distribution of North Atlantic right whales (Eubalaena glacialis) from 2004 to 2014. Sci Rep 7:13460

Delworth TL, Zeng F, Vecchi GA, Yang X, Zhang L, Zhang R (2016) The North Atlantic Oscillation as a driver of rapid climate change in the Northern Hemisphere. Nat Geosci 9:509-512

Fisheries and Oceans Canada (2014) Recovery strategy for the North Atlantic right whale (Eubalaena glacialis) in Atlantic Canadian waters [Final]. Species at Risk Act Recovery Strategy Series. Fisheries and Oceans Canada, Ottawa

Fisheries and Oceans Canada (2018) Scientific advice on timing of the mandatory slow-down zone for shipping traffic in the Gulf of St. Lawrence to protect the North Atlantic right whale. DFO Can Sci Advis Sec Sci Resp 2017/042

Greene CH, Pershing AJ, Cronin TM, Ceci N (2008) Arctic climate change and its impacts on the ecology of the North Atlantic. Ecology 89: S24-S38

Greene CH, Meyer-Gutbrod E, Monger BC, McGarry LP and others (2013) Remote climate forcing of decadalscale regime shifts in Northwest Atlantic shelf ecosystems. Limnol Oceanogr 58:803-816

Grieve BD, Hare JA, Saba VS (2017) Projecting the effects of climate change on Calanus finmarchicus distribution within the U.S. Northeast Continental Shelf. Sci Rep 7: 6264

Hamilton PK, Knowlton AR, Marx MK (2007) Right whales tell their own stories: The photo-identification catalog. In: Kraus SD, Rolland RM (eds) The urban whale: North
Atlantic right whales at a crossroads. Harvard University Press, Cambridge, MA, p 75-104

Harrell FE Jr (2001) Regression modeling strategies (with application to linear models, logistic regression and survival analysis). Springer Series in Statistics, New York, NY

*Hooker SK, Whitehead H, Gowans S, Baird RW (2002) Fluctuations in distribution and patterns of individual range use of northern bottlenose whales. Mar Ecol Prog Ser 225:287-297

Johnson CL, Leising AW, Runge JA, Head EJH, Pepin P, Plourde S, Durbin EG (2008) Characteristics of Calanus finmarchicus dormancy patterns in the Northwest Atlantic. ICES J Mar Sci 65:339-350

Johnson C, Devred E, Casault B, Head E, Spry J (2017) Optical, chemical, and biological oceanographic conditions on the Scotian Shelf and in the Eastern Gulf of Maine in 2015. DFO Can Sci Advis Sec Res Doc 2017/012

Kenney RD (2001) Anomalous 1992 spring and summer right whale (Eubalaena glacialis) distributions in the Gulf of Maine. J Cetacean Res Manag (Spec Issue) 2:209-223

Kenney RD, Hyman MAM, Owen RE, Scott GP, Winn HE (1986) Estimation of prey densities required by western North Atlantic right whales. Mar Mamm Sci 2:1-13

Kraus SD, Prescott JH, Turnbull PV, Reeves RR (1982) Preliminary notes on the occurrence of the North Atlantic right whale, Eubalaena glacialis, in the Bay of Fundy. Rep Int Whaling Comm 32:407-411

Kraus SD, Kenney RD, Mayo CA, McLellan WA, Moore MJ, Nowacek DP (2016) Recent scientific publications cast doubt on the North Atlantic right whale future. Front Mar Sci 3:1-3

Legendre P, Legendre L (2012) Numerical ecology, 3rd edn. Developments in environmental modeling, Vol. 24. Elsevier, Amsterdam

Malik S, Brown MW, Kraus SD, Knowlton AR, Hamilton PK, White BN (1999) Assessment of mitochondrial DNA structuring and nursery use in the North Atlantic right whale (Eubalaena glacialis). Can J Zool 77:1217-1222

Mayo CA, Ganley L, Hudak CA, Brault S, Marx MK, Burke E, Brown MW (2018) Distribution, demography, and behavior of North Atlantic right whales (Eubalaena glacialis) in Cape Cod Bay, Massachusetts, 1998-2013. Mar Mamm Sci 34:979-996

McKinstry CAE, Westgate AJ, Koopman HN (2013) Annual variation in the nutritional value of stage V Calanus finmarchicus: implications for right whales and other copepod predators. Endang Species Res 20:195-204

Mellinger DK, Nieukirk SL, Matsumoto H, Heimlich SL and others (2007) Seasonal occurrence of North Atlantic right whale (Eubalaena glacialis) vocalizations at two sites on the Scotian Shelf. Mar Mamm Sci 23:856-867

Meyer-Gutbrod EL, Greene CH (2018) Uncertain recovery of the North Atlantic right whale in a changing ocean. Glob Change Biol 24:455-464

*Meyer-Gutbrod EL, Greene CH, Sullivan PJ, Pershing AJ (2015) Climate-associated changes in prey availability drive reproductive dynamics of the North Atlantic right whale population. Mar Ecol Prog Ser 535:243-258

Meyer-Gutbrod EL, Greene CH, Davies KTA (2018) Marine species range shifts necessitate advanced policy planning: The case of the North Atlantic right whale. Oceanography (Wash DC) 31:19-23

* Michaud J, Taggart CT (2011) Spatial variation in right whale food, Calanus finmarchicus, in the Bay of Fundy. Endang Species Res 15:179-194 
Murison LD, Gaskin DE (1989) The distribution of right whales and zooplankton in the Bay of Fundy, Canada. Can J Zool 67:1411-1420

NARWC (North Atlantic Right Whale Consortium) (2015) Abstract book. North Atlantic right whale consortium annual meeting 2015, New Bedford, MA

NARWC (2017) Abstract book. North Atlantic right whale consortium annual meeting 2017, Saint Mary's University, Halifax

Pace RM III, Corkeron PJ, Kraus SD (2017) State-space mark-recapture estimates reveal a recent decline in abundance of North Atlantic right whales. Ecol Evol 7: 8730-8741

Parks SE, Brown MW, Conger L, Hamilton PK and others (2007) Occurrence, composition, and potential functions of North Atlantic right whale (Eubalaena glacialis) surface active groups. Mar Mamm Sci 23:868-887

Parks SE, Searby A, Célérier A, Johnson MP, Nowacek DP, Tyack PL (2011) Sound production behavior of individual

Editorial responsibility: Jaume Forcada,

Cambridge, UK (UAS)
North Atlantic right whales: implications for passive acoustic monitoring. Endang Species Res 15:63-76

Saumweber WJ, Durbin EG (2006) Estimating potential diapause duration in Calanus finmarchicus. Deep Sea Res II 53:2597-2617

*Vanderlaan ASM, Taggart CT, Serdynska AR, Kenney RD, Brown MW (2008) Reducing the risk of lethal encounters: vessels and right whales in the Bay of Fundy and on the Scotian shelf. Endang Species Res 4:283-297

Weydmann A, Zwolicki A, Muś K, Kwaśniewski S (2015) The effect of temperature on egg development rate and hatching success in Calanus glacialis and C. finmarchicus. Polar Res 34:23947

Wilson RJ, Banas NS, Heath MR, Speirs DC (2016) Projected impacts of 21st century climate change on diapause in Calanus finmarchicus. Glob Change Biol 22:3332-3340

* Woodley TH, Gaskin DE (1996) Environmental characteristics of North Atlantic right and fin whale habitat in the lower Bay of Fundy, Canada. Can J Zool 74:75-84

Submitted: April 4, 2018; Accepted: February 18, 2019

Proofs received from author(s): June 16, 2019 